\title{
REGULATION OF RAILROAD HOLDING COMPANIES UNDER THE INVESTMENT COMPANY ACT: THE ALLEGHANY CASE
}

THE MAINTENANCE of any workable system of administrative regulation requires a careful allocation of responsibility among the various administrative bodies. ${ }^{1}$ When, however, the activities of a particular company become significant in more than one economic sphere, there arises the possibility of an overlap in the regulatory jurisdiction of two or more agencies. In these circumstances, it is quite possible that dual regulation will be considered impracticable, despite the fact that each agency may assert a discrete, but nonetheless vital, interest in the regulation of that company's activities. Such an impasse appears to have materialized with the recent acquisition of the control of the New York Central R.R. Co. by the Alleghany Corporation. ${ }^{2}$

The Interstate Commerce Commission, ${ }^{3}$ on the one hand, is charged with the duty of supervising railroad holding companies in two respects: First, in order to assure the unification of the country's railway systems in the manner most consistent with the public interest, section 5(2) of the Interstate Commerce Act ${ }^{4}$ provides that acquisitions of the

\footnotetext{
${ }^{I}$ See Landis, The Administrative Process 30 (1938), where a distinction is observed beţween "administrative bodies whose essential concern is the economic functioning of the particular industry and those which have an extended police function of a particular nature." Presumably, the Interstate Commerce Commission would fall into the former category; whereas the Securities and Exchange Commission, in its regulation of securities issuances generally, would fall into the latter, and, in its regulation of public utility holding companies into the former.

2 The annual stockholders' meeting of the New York Central R.R. Co., scheduled for May 26, 1954, was preceded by a much publicized proxy contest between the Central management and the insurgent Alleghany group under the leadership of Robert $R$. Young. On June $I I$, after two adjournments of the meeting, it was announced that the Young interests had acquired control by a $1,062,000$ vote margin. N.Y. Times, June 12, 1954, p. I, col. 8. See id. at p. 27, cols. 5-8, for a chronology of the proxy fight and subsequent proceedings. See also, How Young Got the Votes, Fortune, Aug. 1954, p. 87.

${ }^{3}$ Hereinafter referred to as the ICC.

48 STAT. 217 (1933), as amended, 49 U.S.C. $\S_{5}(2)$ (1952).

"(a) It shall be lawful, with the approval and authorization of the Commission, as provided in subdivision (b) of this section .... (x) ... for a person which is not a carrier to acquire control of two or more carriers through ownership of their stock or otherwise; or for a person which is not $\bar{a}$ carrier and which has control of one or
} 
control of carriers by noncarriers must be approved by the ICC. And, in addition, section 5(3) of the act gives the ICC the power to exercise a continuing regulation over the financial practices of noncarriers that acquire control of carriers. ${ }^{5}$ It is in this latter respect that regulation by the ICC comes into conflict with the regulatory scheme of the Investment Company Act of $1940,{ }^{6}$ administered by the Securities and

more carriers to acquire control of another carrier through ownership of its stock or otherwise. ...

"(b) ... If the Commission finds that, subject to such terms and conditions and such modifications as it shall find to be just and reasonable, the proposed transaction is within the scope of subparagraph (a) of this paragraph and will be consistent with the public interest, it shall enter an order approving and authorizing such transaction, upon the terms and conditions, and with the modifications, so found to be just and reasonable. ...."

The enactment of these provisions in 1933 was precipitated, at first, by the Commission's fear that orderly unification of the nation's railroads might be frustrated by the activities of holding companies. See InTERsTate Commerce Commission, ANnual REPORT 79-83 (1929). The Commission had already determined that its jurisdiction, under the r 920 legislation, to supervise consolidations among carriers was not broad enough to permit it to regulate the acquisitions of control of noncarriers. Stock of Denver \& Rio Grande Western R.R., 70 I.C.C. I02 (1921). In response to the Commission's recommendation, the House Committee on Interstate and Foreign Commerce undertook to investigate the situation. The product of the investigation was a three volume report, Regulation of Stock Ownership in Railroads, H.R. REP. No. 2789, 7 Ist Cong., 3d Sess. (1931), which bore 'out the Commission's fear and recommended an amendment to the act to subject noncarrier acquisitions of control to the Commission's jurisdiction. For a good general discussion of the legislative background of the present $\S_{5}(2)$, see 3 A Sharfman, The Interstate Commerce Commission $430-42$ (1935). For a more technical discussion of the functions of the holding company in effecting railroad consolidations, and of the need for regulation, see BoNBRIGHT AND MEANs, The Holding COMpany 223-318 (1932).

${ }^{4} 48$ STAT. 217 (1933), as amended, 49 U.S.C. $\S_{5}(3)$ (1952). This section provides that whenever a noncarrier is authorized under $\S_{5}(2)$ to acquire control of a carrier, then it "shall, to the extent provided by the Commission in such order, be considered as a carrier subject to any of the following provisions . . . S Sections $20(\mathrm{r})$ (10), 304(a) (1) and (2), 320 and 913 of this title (which relate to reports, accounts and so forth, of carriers), and sections $20 a(2)-(11)$, and 314 of this title (which relate to issues of securities and assumptions of liability of carriers)...." The report provisions are clearly ancillary to the provisions authorizing the regulation of securities issuances. Consequently, it seems that they should be made applicable only if securities issuance regulation is considered necessary. Cf. Memorandum of the SEC as Intervenor, pp. 20-2 I, Louisville \& Jeffersonville Bridge and Railroad Co. Merger, etc., 295 I.C.C. I I (1955).

${ }_{54}$ STAT. 789 (1940), as amended, 15 U.S.C. $\$ \$ 80 a-1$ to $80 a-52$ (1952). The enactment of this statute followed an intensive study of the investment company industry conducted by the SEC pursuant to $\S_{30}$ of the Public Utility Holding Company Act of 1935. 49 STAT. 837 (1935), as amended, 15 U.S.C. \$ 79z-4 (1952). The report of the SEC was submitted to Congress in five parts from June 10, 1938 to June 
Exchange Commission. ${ }^{7}$ This stems from the fact that a corporation like Alleghany, while operating as an investment company, ${ }^{8}$ may, in the course of its normal investment activities, acquire the status of a railroad holding company. ${ }^{9}$ In such a situation, if the ICC properly asserts its section 5(3) power to supervise corporate financing, then the corporation will be entitled to a total exemption under section 3(c)(9) of the Investment Company Act, which excludes from the provisions of that act "any company subject to regulation under the Interstate Commerce Act." $" 10$

This statutory exclusion clearly forecloses any dual regulation by the ICC and SEC. Nevertheless, the essentially dual nature ${ }^{11}$ of the

9, 1941. In addition, six supplemental reports were submitted during that period. This material will hereinafter be cited as SEC REPORT.

For discussion of the statute, see: Jaretzki, The Investment Company Act of 1940 , 26 Wash. U.L.Q. 303 (194I); Thomas, The Investment Company Act of 1940, 9 Geo. Wash. L. Rev. 918 (1941); Tolins, The Investment Company Act of 1940, 26 CORnell L.Q. 77 (1940); Comment, 5o Yale L.J. 440 (.194I); Note 4 I Colum. L. Rev. 269 (194I). See also Barnard, Motley \& Jackson, Federal Regulation of Investment Companies Since 1940,63 HARv. L. REv. II34 (1950); Note, 88 U. PA. L. REv. 584 (1940).

H. R. REP. No. 2639 , 76th Cong., 3d Sess. (1 940 ), contains a section by section summary of the act; and S. REP. No. 1775, 76th Cong., 3d Sess. (1940), contains a topical summary.

${ }^{7}$ Hereinafter referred to as the SEC.

${ }^{8}$ See note 46 infra.

- The Alleghany Corporation registered with the SEC as a nondiversified investment company on November 1,1940 , at which time $95 \%$ of its investments were in railroads and allied securities, including an investment of $\$ 80,000,000$ in the C. \& O. Ry. Co. When the C. \& O. Ry. Co. acquired control of another carrier, the ICC entered an order, pursuant to $\S 5(3)$, subjecting Alleghany to its continuing regulation under $\S 20 a$. See note 15 infra.

${ }^{10} 54$ STAT. 797 (1940), 15 U.S.C. \& 80a-3(c)(9) (1952). The section excludes from the definition of an investment company ". . . any company subject to regulation under the Interstate Commerce Act, or any company whose entire outstanding capital stock is owned or controlled by such a company: Provided, That the assets of the controlled company consist substantially of securities issued by companies which are subject to regulation under the Interstate Commerce Act." The legislative history of this section is discussed in note 86 infra.

A registered investment company which becomes subject to ICC regulation is entitled to an order by the SEC, under $\S 8(f)$ of the Investment Company Act, terminating its registration statement. 54 STAT. 803 (1940), 15 U.S.C. 80a-8(f) (1952). Consequently, Alleghany's registration statement was terminated by the SEC after the ICC order of June 5, 1945. Alleghany Corporation, 20 S.E.C. 73I (1945). See also, The Atlantic Coast Line Co., 9 S.E.C. 680 (194I); II S.E.C. 661 (1942).

11 "The major problem in defining an investment company lay in drawing the line between an investment company and a holding company." Jaretzki, supra note 6 , at 312. Because of this difficulty of classifying certain hybrid forms, the SEC REPORT 
Alleghany Corporation suggests that the conflict should not be resolved in such a categorical manner. Instead, perhaps there is a need for a more delicate coordination between the two commissions in this area. To this end, an examination of the current controversy over the status of Alleghany should prove helpful.

\section{. The Alleghany Controversy}

In May 1954, after an extended proxy contest, ${ }^{12}$ the Alleghany Corporation and its officers acquired effective control of the New York Central R.R. Co. They did so, however, without obtaining the approval of the ICC. ${ }^{13}$ Several months later, Alleghany and New York Central filed with the ICC an application, pursuant to sections 5(2) and 5(3) of the Interstate Commerce Act, for an order approving the merger of

recognized that there were "management investment-holding companies" which exercised a dual function. SEC RePort pt. I, c. I, at I; pt. II, c. II, at 88-94; pt. 4, c. I (dealing extensively with the "quasi-holding company"). In dealing with this problem, $\S_{3}(\mathrm{a})$ of the statute defines an "investment company" as any issuer which "is or holds itself out as being engaged primarily, or proposes to engage primarily, in the business of investing, reinvesting, or trading in securities," or which owns investunent securities having a value exceeding $40 \%$ of the value of such issuer's total assets. In order to insure the exclusion of pure holding companies, $\S_{3}(\mathrm{~b})(2)$ of the act gives the SEC the power to find that a company is "primarily engaged in a business or busincsses other than that of investing; reinvesting, owning, holding, or trading in securities ... through majority owned subsidiaries or through controlled companies conducting similar types of business." 54 STAT. 797 (1940), 15 U.S.C. \$80a-3 (1952). In applying this test, the SEC has said that, "The principal relevant considerations are I) the company's historical development; 2) its public representations of policy; 3) the activitics of its officers and directors; and, most important, 4) the nature of its present assets; and 5) the sources of its present income." Tonopah Mining Co. of Nevada, 26 S.E.C. 426,427 (1947).

${ }^{12}$ See note 2 supra. During the course of this proxy contest, the Alleghany inanagement announced a plan to use the sales force of Investors Diversified Services, Inc. (IDS), an affliated investment company, for the solicitation of proxies. This plan was abandoned after a suggestion by the SEC that it might involve a violation of the Investment Company Act by the officers, directors, and controlling stockholders of IDS. Memorandum of the SEC as Intervenor, p. 6, Louisville \& Jeffersonville Bridge and Railroad Co. Merger, etc., 295 L.C.C. II (1955).

${ }^{13}$ On April 6, 1954, a proceeding was instituted by the New York Central management which sought to obtain a declaratory ruling by the ICC that the proposed acquisition of Central by Alleghany would be in violation of $\S_{5}(4)$ of the Interstate Commerce Act, unless ICC approval was obtained. Alleghany argued, in response, that any such declaratory order would interfere with the stockholders' right to select its own management. On May 18, 1954, the Commission denied Central's petition on the grounds that "to do otherwise would not advance justice." The proceeding is discussed in I.C.C. Finance Docket No. 18656, Report of Division 4 (1955). 
two subsidiaries of New York Central, ${ }^{14}$ and an order designating Alleghany as a noncarrier to be "considered as a carrier" subject to regulation by the ICC. ${ }^{15}$ The SEC was permitted to intervene in this proceeding for the limited purpose of submitting memoranda ${ }^{16}$ requesting the ICC, in its discretion, not to assert its jurisdiction, but to defer to the SEC because Alleghany was still operating preponderantly as an investment company. Despite this request, both orders were granted

${ }^{16}$ In fact, the two merging subsidiaries also joined in the application. The proposal was to merge the properties of the Louisville \& Jeffersonville Bridge and Railroad Co. into the properties of the Cleveland, Cincinnati, Chicago and St. Louis Railway Company, hereinafter referred to as the Big Four, for ownership, management, and operation; and, also, for modification of a lease pursuant to which New York Central, as lessee, operates the property of the Big Four. At the time of the application, New York Central owned $98.98 \%$ of the common, and $86.45 \%$ of the outstanding preferred stock of the Big Four; and, in turn, the Big Four owned the entire capital stock of the Jeffersouville Co. It was stated in the application that Alleghany, with New York Central, indirectly controlled Jeffersonville through the Big Four. Presumably, the theory of the application was, that by virtue of the merger, Alleghany's control of the properties of Jeffersonville would now be more direct. Louisville \& Jeffersonville Bridge and Railroad Company Merger, etc., I.C.C. Finance Docket No. I8656, Report of Division 4 (1955).

${ }^{15}$ More specifically, the application, as it pertained to Alleghany, requested "continuation of Alleghany's status as a carrier" rather than a new order designating Alleghany as a carrier. The basis for the implication that Alleghany already was "considered as a carrier" at the time of the application lies in the terms of an ICC order issued June 5, r945, in a proceeding involving Alleghany's "acquisition," through its control of the C. \& O. Ry. Co., of the properties of the Norfolk Terminal \& Transportation Co. At that proceeding, the ICC provided in its order that Alleghany shall be considered as a carrier "unless and until otherwise ordered by this Commission." C. \& O. Ry. Co., Purchase, 26I I.C.C. 239, 26I (r945). Shortly thereafter, the SEC entered its order, pursuant to $\S 8(f)$ of the Investment Company Act, which stated that if ICC regulation should cease, the SEC registration would be reinstated after appropriate notice and hearing. Alleghany Corporation, 20 S.E.C. 73 I (I945). See note Io supra. Accordingly, even though on Jan. I9, I954, Alleghany had divested itself of ownership of its C. \& O. stock, it took the position in the federal district court proceeding on the preliminary injunction, that the minority stockholders were not prejudiced if the later ICC orders were invalid, because Alleghany had acquired 'carrier" status in the C. \& O. proceeding in 1945. It was argued that the 1945 order was still valid since the ICC had not "otherwise ordered." In addition, it was urged that the SEC exemption was still operative, since no further hearing had been held. These contentions were rejected both in the first district court opinion on the preliminary injunction, Breswick v. United States, I34 F. Supp. I32, I42 (S.D.N.Y. I955), and in the final district court opinion invalidating the ICC orders. $138 \mathrm{~F}$. Supp. $123,128-130$ (S.D.N.Y. 1955). This issue is one of the questions presented on appeal to the Supreme Court. Appellant's Statement as to Jurisdiction, p. 6, Alleghany Corp v. Breswick \& Co., appeal granted, 24 U.S.L. WeEk 3277 (U.S. April 24, 1956) (No. 692).

10 The SEC submitted a memorandum dated Sept. I4, I954, and supplemental memoranda dated Sept. 28, 1954, and Dec. 14, 1954. 
by the ICC.17 Accordingly, when Alleghany later planned the issuance of a new class of preferred stock pursuant to a voluntary exchange offer, it sought the approval of the ICC. ${ }^{18}$ The issuance was approved; ${ }^{10}$ but before it could be consummated, distribution of the stock was suspended by a temporary restraining order obtained by minority stockholders of Alleghany, ${ }^{20}$ who, objecting to the company's immunity from regulation under the Investment Company Act, had attacked the jurisdiction of the ICC..$^{21}$ Thereafter, a three-judge district court issued a

${ }^{17}$ Louisville \& Jeffersonville Bridge and Railroad Company Merger, etc., I.C.C. Finance Docket No. 18656, Report of Division 4, aff'd., 295 I.C.C. II (1955).

${ }^{18}$ By application filed Feb. 18, 1955, Alleghany sought the authorization of the ICC under $\$ 20 a$ of the Interstate Commerce Act, to issue $1,367,440$ shares of $6 \%$ convertible preferred stock in exchange for its outstanding cumulative $5 \%$ preferred stock, and to issue $14,768,352$ shares of common stock upon conversion of the $6 \%$ preferred. The proposed exchange had been approved at a special meeting of Alleghany stockholders on Feb. 8, I955; and, on the same day, appropriate amendments to the certificate of incorporation had been filed with the state officials. In the ICC proceeding, certain minority stockholders were permitted to intervene, and contended that the convertible feature of the new preferred stock would so substantially dilute the equity of the existing stockholders as to make the plan unfair. The Commission, through its Division 4, rejected this contention and concluded that the issue was appropriate by the standards of $\S 20 a$. Alleghany Corporation Stock, Finance Docket No. 18866, Report of Division 4 (1955).

${ }^{10}$ On May 26, 1955, the full Commission adopted the report of Division 4, and formally authorized the issuance of the stock. Alleghany Corporation Stock, Finance Docket No. I 8866 (1955).

${ }^{20}$ The temporary restraining order, although not reported officially, was issued on June 23, 1955, at 6:30 P. M., ex parte, and restrained Alleghany, its tranfer agent, and the exchange agent, from further distributing, issuing or transferring the $6 \%$ preferred stock. By that time, 900,000 of the 1,300,000 shares had already been delivered to the shareholders who were participating in the exchange. Appellant's Statement as to Jurisdiction, Alleghany Corp. v. Breswick \& Co., appeal granted, 24 U.S.L. WEEK 3277 (U.S. April 24, 1956) (No. 692).

${ }^{21}$ In addition, essentially the same minority stockholders, as plaintiff, had brought a stockholders' derivative action to recover for the directors' alleged conspiracy to use the corporation's facilities for their own personal gain. In Sept. 1955, the plaintiffs moved for a summary judgment as to five of their seven courts. Plaintiffs also moved for a stay of settlement proceedings by other minority stockholders in the New York State Supreme Court. Defendants moved to consolidate this action with other derivative actions already consolidated and for the designation of a general counsel for all the consolidated actions. In an order by Judge Walsh, on Sept. 28, 1955, the plaintiff's motion for summary judgment was denied in full. The court refused to stay the settlement proceedings in the state court, but enjoined the defendants froin using any state court judgment as a defense against these plaintiffs. The court also denied the defendant's motion to consolidate. Breswick \& Co. v. Briggs, I35 F. Supp. 397. (S.D.N.Y. 1955.) 
preliminary injunction continuing the restraining order ${ }^{22}$ and, eventually, the same court entered a final judgment ${ }^{23}$ invalidating both the ICC order asserting jurisdiction over Alleghany and the order approving the issuance of the new preferred stock. Appeals by Alleghany and the $\mathrm{ICC}^{24}$ are now pending before the Supreme Court. ${ }^{25}$

The more important of the questions raised by the litigation are: first, whether issuance of the section 5(3) order asserting jurisdiction over the Alleghany Corporation was within the power of the ICC; and second, if so, whether the ICC should surrender its jurisdiction to the SEC. ${ }^{26}$

${ }^{22}$ Breswick \& Co. v. United States, ${ }_{34}$ F. Supp. ${ }_{32}$ (S.D.N.Y. 1955). Circuit Judge Hincks dissented, primarily on the ground that the plaintiffs had not adequately demonstrated that they would be irreparably damaged in the absence of injunctive relief. He argued that the plaintiff's assertion of irreparable damage depended entirely on a showing that the terms of the preferred stock issue were such that it would be disapproved by the SEC if Alleghany were subjected to its jurisdiction under the Investment Company Act. No such showing, in his opinion, had been made. By inadvertence, Judge Hincks' opinion was not reported with the majority opinion in 134

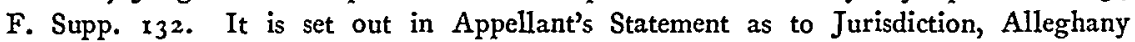
Corp. v. Breswick \& Co., appeal granted, 24 U.S.L. WEEK 3277 (U.S. April 24, 1956) (No. 692).

${ }^{23}$ Breswick \& Co. v. United States, 138 F. Supp. 123 (S.D.N.Y. 1956), noted in 69 HaRv. L. REV. 1335 (1956). Prior to this proceeding, but subsequent to the proceeding for the preliminary injunction, Alleghany made application to Justice Harlan, as a circuit judge, for an order staying the district court's preliminary injunction pending appeal to the Supreme Court. After carefully evaluating the possibilities of prejudice to the plaintiffs and to Alleghany's other stockholders, Justice Harlan granted the stay as to the 900,000 shares of preferred stock already distributed. The stay was conditioned, however, on Alleghany's posting a $\$ 14,000$ bond indemnifying the plaintiffs against any loss which might result from the dilution of their equity as common stockholders by the exercise of the conversion privilege in the $6 \%$ preferred. Notwithstanding the stay order, trading in the entire issue of the $6 \%$ preferred remained suspended on the New York Stock Exchange; and the National Association of Securities Dealers admonished its member firms against trading in the issue. For all practical purposes, then, the stay was of no value. Appellant's Statement as to Jurisdiction, Alleghany Corp. v. Breswick \& Co., appeal granted, 24 U.S.L. WEEK 3277 (U.S. April 24, 1956) (No. 692).

${ }^{24}$ Notice of Appeal by the Interstate Commerce Commission to the Supreme Court of the United States, Breswick \& Co. v. United States, 138 F. Supp. 123 (S.D.N.Y. 1956), filed March 23, 1956. The United States has not appealed.

${ }_{25}$ Appeal granted, 24 U.S.L. WEEK 3277 (U.S. April 24, 1956) (No. 692).

${ }^{20}$ Other questions raised by the appeal concern the standing of the minority shareholders to seek review of the ICC orders, and the propriety of the ICC's failure to grant plaintiffs a hearing. Appellant's Statement as to Jurisdiction, Alleghany Corp. v. Breswick \& Co., appeal granted, 24 U.S.L. WEEK 3277 (U.S. April 24, 1956) (No. 692). 


\section{Validity of the ICC Order:}

It is clear that the ICC may. subject a noncarrier to its continuing supervision by an order under section 5(3) only when there is an accompanying order under section 5(2) approving an "acquisition of control" by the noncarrier. ${ }^{27}$ In its attempt to come within the ICC jurisdiction under section 5(3), Alleghany proceeded somewhat indirectly, applying not for approval of its control relationship with New York Central, but rather for approval of a merger of two New York Central subsidiaries. ${ }^{28}$ The Commission, relying on past decisions indicating that such an intercorporate re-arrangement could be an "acquisition of control" within the meaning of the statute, ${ }^{29}$ approved the merger, and, on that basis, designated Alleghany as a "carrier" for purposes of ICC supervision. ${ }^{30}$ The district court, however, in nullifying the ICC orders, disagreed with the Commission's interpretation of the statute and held that an intercorporate re-arrangement could not constitute an acquisition of control..$^{31}$ Therefore, the court concluded, the Commission could not assert general jurisdiction over Alleghany without first approving its control of New York Central..$^{32}$

\footnotetext{
${ }^{27}$ See note 5 supra.

${ }^{28}$ See note 14 supra.

${ }^{29}$ See, for example, Nicholas, Fayette \& Greenbrier R.R. Co. Lease, 26 I I.C.C. 546 (1945); Chesapeake \& Ohio Ry. Co. Purchase, 26r I.C.C. 239 (1945); Saginaw Dock \& Terminal Co.-Contract Carrier Application, 260 I.C.C. 657 (1945); Warrior \& Gulf Nav. Co. Control, 250 I.C.C. 26 (1941); United Parcel Service of Portland-Purchase-Wiese, 37 M.C.C. 473 (r 94 I); Atchison, T. \& S. F. Ry. Co.-Control-Santa Fe Trail Trans., 15 M.C.C. 469 (1938).

${ }^{30}$ Louisville \& Jeffersonville Bridge and Railroad Co. Merger, Etc., 295 I.C.C. I I (1955).

${ }^{31}$ Understandably, the district court in both proceedings opposed the proposition that the statutory requirement of acquisition of control could be met by a merger of two subsidiaries which already were controlled by Alleghany. In its opinion in the preliminary injunction proceeding, the court was emphatic in its rejection of the Commission's interpretation of the statute. 134 F. Supp. 132, 143 (S.D.N.Y. 1955).

In the proceeding for the final injunction, the court pointed out that if the Commission had been consistent in its interpretation of $\S_{5}(2)$, the court might be disposed to give its construction greater deference. However, the court was of the opinion that the ICC had not been consistent in its application of the statute to intercorporate rearrangements. 138 F. Supp. 123, 128 (S.D.N.Y. 1956).

${ }^{32}$ The first opinion of the district court raises an interesting collateral issue which may have considerable significance in any subsequent proceedings. The court took the position that even though Alleghany sought carrier status by virtue of the merger of the Central subsidiaries, nevertheless, implicit in its application was the assertion that it controlled Central. Accordingly, the court felt that the ICC could have made appropriate findings as to Alleghany's control of Central in the merger proceeding. 134
} 
It would appear that the district court was correct only in its conclusion. There is substantial basis for the ICC's less restrictive interpretation of "acquisition of control"; ${ }^{33}$ and it is likely that the court's reasoning on this point was unnecessarily influenced by its conviction that the ICC should not regulate Alleghany under section 5(3) without first approving its control of New York Central. ${ }^{34}$ This conclusion, however,

F. Supp. 132, 145 (S.D.N.Y. 1955). The court then went on to explore the possibility that the ICC had, by implication, made adequate findings in its opinions dealing with the merger. After first concluding that the ICC had not found that Alleghany's control of Central was in the public interest, the court then examined the Commission's conclusion on the issue of control alone. The court adverted to language in the opinion by the ICC's Division 4, and by the full Commission, to the effect that it was not Alleghany alone that controlled New York Central, but rather "Alleghany and its officers" or "Alleghany and its allied interests." Consequently, the court suggested that Alleghany might not control Central within the meaning of $\$ 5(2)$, since its interpretation of that section would indicate that sole control is required. I 34 F. Supp. 1 32, 146-r47 (S.D.N.Y. I955).

It is unlikely that the court's concern on this point is well-founded. In the only Supreme Court opinion dealing with $\S_{5}(2)$, the Court pointed out that the statute defined "control" to include "actual as well as legal control ... through or by common directors, officers, or stockholders, a voting trust or trusts, a holding or investment company or companies, or through or by any other direct or indirect means. . .." United States v. Marshall Transport Co., 322 U.S. 31, $3^{8}$ (1944). Alleghany's control over New York Central, despite the cooperative interests of its officers, would certainly come within this language.

${ }^{33}$ The ICC's interpretation is simply intended to require a noncarrier to obtain the Commission's approval whenever a railroad company, whose ultimate parent is controlled by the noncarrier, is reorganized in a manner which results in the noncarrier's control over the company being less indirect. Nicholas, Fayette \& Greenbrier R.R. Co. Lease, 26 I I.C.C. 546 (1945). Thus, in the instant proceeding, as a result of the merger between Jeffersonville and the Big Four, Alleghany's control of Jeffersonville, through New York Central, would be asset control rather than stock control. Since the definition of "control" in the Interstate Commerce Act is extremely broad [see the opinion in United States v. Marshall Transport Co., 322 U.S. 3 I, 38 (I944)], there would be no difficulty in designating such a reorganization an "acquisition of control" by Alleghany. In addition, since $\$ 5(2)$ clearly requires the ICC's approval of the merger, it would hardly be unreasonable if the noncarrier were" required to be a party to the proceeding. In fact, the only conceivable objection to the ICC's interpretation of $\S_{5}(2)$, is the erroneous notion, both of the district court and of the ICC, that such an "acquisition of control" can support a $\$_{5}(3)$ order. It seems fairly certain that this would be improper. See text to note 35 infra. And, accordingly, there appears to be little justification for the district court's rejection of the Commission's interpretation of $\S_{5}(2)$. But see 69 HARv. L. REV. 1335, I336 (1956).

${ }^{36}$ The ICC seemed to justify its failure to approve the acquisition of the control of New York Central on two grounds: first, that Central is a "system" rather than a "carrier;" and, second, that this was not really an "acquisition of control," but merely a change in the board of directors. Louisville \& Jeffersonville Bridge and Railroad Co. Merger, etc., 295 I.C.C. II, I5-I7 (1955). Both of these arguments had 
could have been reached more directly. Even adopting the Commission's interpretation of the statute, the merger of the New York Central subsidiaries could not establish or solidify Alleghany's control over either of them unless it was presumed that Alleghany controlled New York Central. Such unapproved control, however, is prohibited by the Interstate Commerce Act. ${ }^{35}$ Accordingly, the district court could easily have refused to recognize Alleghany's status as a "carrier" regulated by the ICC, since that status was entirely dependent on an unlawful control relationship.

In sum, it seems clear that the ICC's jurisdiction-assuming order was invalid. But that invalidity may easily be corrected by appropriate findings as to Alleghany's control relationship with New York Central.

\section{The Regulatory Interests of the Two Commissions}

Assuming, then, that the ICC could have the power to issue the section 5(3) order, there remains the broader question of whether this assumption of jurisdiction would best serve the interests of the public. This problem must be resolved by an evaluation of the respective purposes sought to be promoted by ICC and SEC regulation. ${ }^{36}$

\section{ICC Regulatory Interests:}

Both the ICC and the majority stockholders of the Alleghany Corporation assert generally that Alleghany should be considered as a carrier under section 5(3) because "its influence on the national transportation system ... is immediate in effect and wide in scope."37 When analyzed in more specific terms, however, this influence appears somewhat less formidable. It is quite true that the Alleghany manage-

been rejected by the Division 4 report, which, nevertheless, had concluded that approval of the control of Central was unnecessary. I.C.C. Finauce Docket No. 18656, Report of Division 4, Sheets 9 \& 16 (1955).

${ }^{35} 48$ STAT. 218 (1933), as amended, 49 U.S.C. \$ $5(4)$ (1952). "It shall be unlawful for any person, except as provided in paragraph (z) of this section, to enter into any transaction within the scope of subparagraph (a) of paragraph (2) of this section, or to accomplish or effectuate ... the coutrol or management in a common interest of two or more carriers, however such result is attained. . . " Curiously, the ICC made no reference to this section in their opinions.

${ }^{36}$ In the proceeding on the preliminary injunction, the district court adverted to the problem of whether the ICC, assuming it had jurisdiction to submit Alleghany to its regulation, should have deferred its regulation in favor of the SEC; but the point was not discussed. 134 F. Supp. 132, 145 (S.D.N.Y. 1955).

${ }^{37}$ Louisville \& Jeffersonville Bridge \& Railroad Co. Merger, etc., I.C.C. Finance Docket No. 18656, Report of Division 4, Sheet 16 (1955). 
ment 'is now operating under a policy of simplifying Central's corporate organization, and from time to time will apply for authority to change the internal structure thereof by merger, consolidations, leases, and/or other acquisitions of property."38 But it is also true that the ICC can adequately supervise this simplification by exercising its section 5(2) power to approve or disapprove the various corporate changes as they are proposed. Consequently, it seems that this particular aspect of Alleghany's influence on the national transportation system does not necessitate a continuing regulation by the ICC under section $5(3) .^{39}$

Such continuing regulation is more convincingly urged on the ground that the ICC is vitally concerned with the "corporate structure and financial practices of companies which control subsidiary carrier companies."40 This concern, however, seems to be largely limited to the prevention of capital inflation and top-heavy senior securities. ${ }^{41}$ These deficiencies in the capital structure of a holding company may, of course, have an adverse effect on the efficiency of the operating companies. ${ }^{42}$

${ }^{38}$ Louisville \& Jeffersonville Bridge and Railroad Co. Merger, etc., I.C.C. Finance Docket No. I8656, Report of Division 4, Sheet 5 (1955). This reference to the policies of the Alleghany management was made in the course of the opinion of $\mathrm{Di}$ vision 4 approving the merger application submitted by Alleghany and the New York Central. See also, Planning to Remake the Central, Business Week, June I2, 1954, p. 27. Also, in this connection, it has been said that Robert R. Young first came into railroad prominence in 1947, advertising: "A Hog Can Cross the Country Without Changing Trains, But You Can't." N.Y. Times, June 12, 1954, p. 27 , col. 1.

${ }^{30}$ The continuing regulation authorized by $\S_{5}(3)$ is primarily the regulation of "issues of securities and assumptions of liability" under $\$ 20 a$. See note 5 supra. With respect to $\S_{20 a} \S_{5}(3)$ provides that "the Commission shall authorize the issue or assumption applied for only if it finds that such issue or assumption is consistent with the proper performance of its service to the public by each carrier which is under the control of such person, that it will not impair the ability of any such carrier to perform such service, and that it is otherwise consistent with the public interest."

${ }^{40}$ Louisville \& Jeffersonville Bridge and Railroad Co. Merger, etc., I.C.C. Finance Docket No. 18656, Report of Division 4, Sheet 13 (1955).

${ }^{41}$ For an extensive examination of ICC regulation under $\$$ zoa, see LockLIN, Regulation of Security Issues by the Interstate Commerce Commission (1925). See also 3-A SHARFMAN, op. cit. supra note 4 , at 502-54. The prevention of overcapitalization, however, is not the sole concern of the ICC under $\$ 20 a$. For example, under its broad grant of authority, the ICC has, with certain exceptions, required the use of competitive bidding in the sale of rail securities. See In re Competitive Bidding in Sale of Securities, 257 I.C.C. I29 (1944); 49 C.F.R. § 56.25 (Supp. I956). In addition, the ICC has been concerned with maintaining a proper relationship between capital investment and corporate control. See note 58 infra.

${ }^{12}$ See Bonbright and MeAns, op. cit. supra note 4, at 308-10 (1932). A similar problem arises in connection with public utility holding companies. Cf. id. at $158-74$; Guthmann and Dougall, Corporate Financial Policy 549-50 (1948). 
For example, any type of financially unsound capitalization could well encourage a controlling corporation to accelerate the dividend payments of the operating carrier, which, in turn, might jeopardize the financial condition of the latter and discourage the reduction of traffic rates. ${ }^{43}$ In addition, it has been suggested that the unfavorable financial condition of a holding company will reflect on the credit of the operating subsidiary, thus limiting its sources of new capital. ${ }^{44}$ Nevertheless, it must at least be recognized that these adverse effects are somewhat attenuated ${ }^{45}$ when, as in the case of Alleghany, the controlling corporation is primarily an investment company, the portfolio of which is largely composed of noncarrier securities. ${ }^{46}$

${ }^{43}$ Commissioner Eastman of the ICC, testifying before the House Committee on Interstate and Foreign Commerce, on April 5, 9, and 10, 1930, expressed the opinion that "when capitalization [of railroad holding companies] is inflated, every possible effort will be made to secure the excessive earnings which are necessary to support it. ... Overcapitalization also invites attempts to drain off profits surreptitiously in various indirect ways. ..." House Committee on Interstate and Foreign Commerce, Regulation of Stock Ownership in Railroads, H. R. REP. No. 2789 , 71st Cong., 3 d Sess. $x(1931)$.

"Bonbright ANd MEANs, op. cit. supra note 4, at 167-70 (1932). Also, Commissioner Eastman testified that "an inflated capitalization in the long run means poor credit. . . . H. R. REP. No. 2789 , op. cit. supra note 43 , at X.

"See, e.g., Bonbright and MEANs, op. cit. supra note 4, at 295 . Cf. id. at 168-69, with primary reference to public utility holding companies: "For, while it is true that a financially weak holding company will almost inevitably impair the capitalraising powers of its operating subsidiaries, it is also true that there is a certain degree of independence between the credit of the parent company and the credit of its subsidiaries."

${ }^{46}$ In its original memorandum, the SEC indicated that only $16 \%$ of Alleghany's $\$ 67,000$,00o portfolio was invested in railroad stock. Memorandum of the SEC as Intervenor, pp. 4-7, Louisville \& Jeffersonville Bridge and Railroad Co. Merger, etc. 295 I.C.C. II (1955). In its reply, filed October 14, 1954, Alleghany pointed to the acquisition of additional shares of Central stock and of other rail securities, and estimated its present investments in railroad securities at $52 \%$ of its portfolio. In addition, it represented to the ICC that it intended to divest itself of is non-rail securities as soon as practicable, and expected that its portfolio would eventually consist of not less than $75 \%$ in railroad securities. Louisville \& Jeffersonville Bridge and Railroad Company Merger, Finance Docket No. 18656 , Report of Division 4, Sheet 13. Responding to Alleghany's reply by a supplemental memorandum, the SEC adhered to the figures on Alleghany's investments given in its prior memorandum. "Alleghany's substantially different figures (Reply p. 10), apart from minor portfolio changes since July, 1954, are based on cost rather than present worth valuations (Reply p. 5). The SEC believes that any here meaningful analysis of Alleghany's investments must be founded on current market valuations rather than cost, as would, indeed, be required under the Investment Company Act $\left[\$_{2}(\mathrm{a})_{39}\right]$." Second supplemental memorandum of the SEC as Intervenor, p. 6, n. 9, Louisville \& Jeffersonville Bridge and Railroad 
Even aside from this mitigating factor, however, it seems that the need for ICC regulation is satisfied by certain provisions in the Investment Company Act that were drafted to check disproportionate debt financing and capital inflation. First, in order to assure an equity capital sufficient to cushion all fixed payment obligations, ${ }^{47}$ section I8(a) of the act prohibits registered closed-end investment companies from selling their bonds or preferred stock unless immediately after such issuance or sale there will be an asset coverage of at least 300 or 200 per cent respectively. ${ }^{48}$ Also, in order to prevent dilution of the common stockholders' equity, ${ }^{40}$ section 23 (a) provides that such companies

Company Merger, etc. 295 I.C.C. I I (1955). In response to Alleghany's representations as to its prospective emphasis on railroad securities, the SEC took the position that, "So long as these security holdings are too small to involve control, or are placed in trust so as to isolate them from control by Alleghany, they are clearly being held as investments, and as to such holdings Alleghany would remain in the position of an investment company, not that of a carrier." Id. at ro. Of interest in con. nection with Alleghany's "prospective portfolio," is the announcement by its directors on May $\mathrm{I}$, 1956, that the Corporation plans to invest $\$ 20,000,000$ in the securities of Webb \& Knapp, Inc., a realty organization. Standard \& Poor's, Daily News Sec. tion, May 2, 1956, p. 8577 .

4" "[T] he amount paid in for the equity securities constitutes a cushion for the senior securities in the sense that the company can sustain a loss in assets equivalent to that amount without impairing the liquidation values of the senior securities. This margin of insulation from loss is the chief virtue claimed for the senior securities." SEC REPORT pt. 3, c. V, at 1665 . The SEC REPORT cites several instances of inadequate "junior" money. Id. at $\mathrm{r} 666-68$.

${ }^{8} 54$ STAT. 817 (1940), I5 U.S.C. §80a-I8(a) (1952). Section I8(e) of the statute, however, exempts from these restrictions "any senior securities issued or sold by any registered closed-end company .... (2) for the purpose of refunding through payment, purchase, redemption, retirement or exchange, any senior security of such registered investment company. . . " There is a possibility that this exemption might exclude from the requirements of the act the issuance of Alleghany's new preferred stock, since that issue was made pursuant to an offer for the exchange of the $6 \%$ cumulative convertible preferred for the $\$ 5.50$ cumulative preferred. See note 18 supra. The SEC believes, however, that, because of the convertible feature, the new preferred stock was in the nature of a warrant. Such an interpretation would not only exclude the exchange offer from the $\S$ x $\$(\mathrm{e})$ exemption; it would also render it illegal under $\S \mathrm{I} 8(\mathrm{~d})$, which provides that investment companies may not issue warrants to purchase their securities unless the warrants must expire within 120 days. Interviews with staff members of the office of the General Counsel of the Securities and Exchange Commission. Cf. $\S 25$ of the statute, which gives the SEC certain supervisory powers over all reorganization plans with respect to registered investment companies. 54 STAT. 826 (1940), 15 U.S.C. \& Soa-25 (1952).

Section $18(\mathrm{a})$ furthermore provides that every issue of bonds or preferred stock must contain a clause prohibiting the declaration of dividends on any stock unless there will be, immediately after the payment of the dividends, an asset coverage of $300 \%$ or $200 \%$ respectively.

"See Note, 4I Colum. L. Rev. 269, 283 (I94I). Also directed to the "dilu- 
may issue securities only for cash or other securities, except in connection with a reorganization or a stock dividend; and section $23(\mathrm{~b})$, with certain exceptions, prohibits the issuance of common stock at a price below the current net asset value. ${ }^{50}$

The contrast between the definitive nature of these tests and the vagueness of the standard under the Interstate Commerce Act ${ }^{51}$ suggests a difference between the problem of unsound capitalization as it relates to investment companies which control carriers and as it relates to the operating carriers themselves. In this latter area, the ICC has, in large part, been concerned with determining what assets are capitalizable ${ }^{52}$ and how they should be valued. ${ }^{53}$ For example, operating companies may seek authority to issue securities for the purpose of financing new construction and improvements, ${ }^{54}$ or to capitalize expenditures already made for those purposes. ${ }^{55}$ These are not the type of problems that will normally arise in the case of an investment company, however; ${ }^{\text {60 }}$ and it is therefore understandable that the emphasis of sections 18 and 23 of the Investment Company Act is quite different. These sections were especially designed to insure the financial well-being of companies

tion", problem is $\S 18(d)$, which proscribes the issuance of warrants which will not expire within 120 days. See note 48 supra.

${ }_{54}$ STAT. 825 (1940), 15 U.S.C. \& 80a-23 (1952).

${ }^{81}$ For the standards prescribed by $\S_{5}(3)$ for $\oint_{20 a}$ regulation, see note 39 supra. Section $20 a$ itself provides merely that the Commission shall approve issuances of securities and assumptions of liability "only if it finds that such issue or assumption: (a) is for some lawful object within [the carrier's] corporate purposes, and compatible with the public interest, which is necessary or appropriate for or consistent with the proper performance by the carrier of service to the public as a common carrier, and which will not impair its ability to perform that service, and (b) is reasonably necessary and appropriate for such purpose." 49 STAT. 543 (1935), as amended, 49 U.S.C. $\$ 20 a(2)$ (1952). The amplification of these standards is left to the administrative process. See references cited in note 4 I supra.

${ }^{53}$ See Locklin, Capitalizable Assets, op. cit. supra note $4 \mathrm{I}$ c. V; 3 A SHarfman, op. cit. supra note 4, at 508-II. For a collection of ICC cases on this point, sec Interstate Commerce Acts Annotated, $\S 20 a(2)$, nn. 25-41. A closely related matter, which has frequently occupied the Commission's attention, is whether to allow the capitalization of earned surplus by stock dividends. See LockLIN, stipra c. XIII; $3 \mathrm{~A}$ SHARFMAN, supra at 513-26; Trona Ry. Co. Stock, 275 I.C.C. 610 (1950) (authority to declare preferred stock dividend denied); Interstate Commerce Acts Annotated, $\S 20 a(2)$, n. II3.

${ }^{53}$ See LockLIN, Valuation for Purposes of Capitalization, op. cit. supra note $4 \mathrm{I}$,

c. VI; 3 A SHARFman, op. cit. supra note 4 , at $511-13$.

${ }^{54}$ E.g., Brimstone R. Co. Stock, 252 I.C.C. 91 (1942).

${ }^{6}$ E.g., New Orleans G. N. Ry. Co. Bonds, 254 I.C.C. 794 (1944).

${ }^{\text {re }}$ See Jaretzki, supra note 6 , at 328 (194I). 
like Alleghany; $;^{57}$ and if, under the administration of the SEC, they accomplish that end, then it is quite unlikely that the purposes of the Interstate Commerce Act will be frustrated.

Closely related to this problem of securing financial stability is the problem of maintaining a proper relationship between capital investment and corporate control. This is undoubtedly a matter of some concern to the ICC, as it has been recognized that too wide a divergence between ownership and control in the transportation industry can be detrimental to the public interest in several respects. ${ }^{58}$ The mischief with which the ICC is concerned in this connection, however, seems quite overshadowed by the abuses to which certain provisions of the Investment Company Act are directed.59 The Report of the SEC which led to the passage of that act revealed that complex capital structures frequently enabled investment company sponsors to acquire complete control with a disproportionately small investment. ${ }^{60}$ Typically, the major capital contributions would be made by the nonvoting senior security holders, while the sponsors would take a majority of the voting common stock. ${ }^{61}$ This development naturally resulted in a leverage position ${ }^{62}$ almost certain to invite speculative management; ${ }^{63}$

\footnotetext{
${ }^{67}$ In addition to the provisions of $\S_{1} 8(\mathrm{a})$ (see note 48 supra), $\S_{19}$ prohibits the payment of dividends out of capital or capital gains unless the source of the dividends is disclosed. See Jaretzki, supra note 6, at 335-38 (194I) ; Note, 88 U. PA. L. Rev. 584,596 (1940).

${ }^{68}$ See ${ }_{3}$ A Sharfman, op. cit. supra note 4 , at $534^{-42}$. In speaking of the separation between ownership and control, Professor Sharfman says the ICC has realized "that developments of this character in the field of railroad finance may jeopardize the credit of the carriers and impair the transportation service." Id. at 534.

${ }^{80}$ See FlynN, Investment Trusts Gone Wrong 33-5I (r93 $\mathrm{x}$ ); Comment, 50 YAle L. J. 440, 449-5I (I94I); Notes, 4I Colum. L. Rev. 270, 273 (I94I), 88 U. PA. L. REv. 584, 590-600 (1940).

"o "[T] he complex capital structure company is a suitable vehicle for promoters who desire by a small proportionate investment to achieve immediate and prospective control of the company and at the same time receive an inordinate participation in prospective profits." SEC REPORT pt. 3, c. V, at 1597 . See Id. Appendix I, at 1937-40, for tables showing the proportion of total capital of four investment companies contributed by senior and junior security holders, and the sponsors' interest therein.

${ }^{01}$ The SEC REPORT cited specific instances in which control was concentrated by the use of debentures or preferred stock, Id. at 1598-620; and instances in which control was concentrated by the use of Class B, nonvoting common stock, Id. at $1620-41$.

62 See Jaretzki, supra note 6, at 306. "The larger the amount of senior securities issued relative to the funds contributed by common stockholders the greater the possible gain to common stockholders-and, of course, the greater the risk that the entire junior money may be wiped out, at least temporarily." SEC REPORT pt. 3, c. V at 1582 .

${ }^{63}$ c'The senior-equity set-up creates such a disparity between the possible profits to
} 
and, furthermore, it facilitated transfer of control in times of declining profits. ${ }^{64}$ Such practices would clearly have adverse effects on the transportation industry if they were allowed to prevail among railroad holding companies. ${ }^{65}$ Consequently, since the express provisions of the Investment Company Act offer the more stringent safeguards, ${ }^{60}$ it appears that the public interest would best be served by SEC regulation of this particular problem.

\section{SEC Regulatory Interests:}

In addition to these few areas in which the ICC and the SEC have a similar concern in the regulation of investment companies, there are many others in which the problems to be met are distinctively within the compass of the Investment Company Act. ${ }^{67}$ By holding out to the general public the promise of diversified investment risk and expert

the sponsor from a speculative policy and the possible losses to the sponsor therefrom as to make the temptation to pursue such a policy almost irresistible to the sponsor." SEC REPorT pt. 3, c. V at 1670 . The SEC REPORT cites, as a case in point, the speculative activities of the United States \& International Securities Corporation, which was formed by Dillon, Read \& Co. on a 5 to $x$ leverage basis. Id. at $\times 673-74$.

${ }^{6}$ See, generally, SEC REPORT pt. 3, c. V, at 1641-64, for specific examples of "trafficking in investment companies." "[T] he management of the company may be passed on without the consent of the investors who have contributed the bulk of the funds. The Study has demonstrated that comparatively rarely docs the purchaser of control from a previous sponsor seek control for the purpose of strengthening the position of the investor in the company."

${ }^{\mathrm{BS}}$ See note 58 supra.

${ }^{06}$ Most of these safeguards are provided by $\S 18$ of the act. 54 STAT. 817 (1940), 15 U.S.C. $\$ 80 a-18$ (1952). Section 18 (a) (1) (c) (i) requires that each issue of bonds contain a clause to the effect that if the asset coverage of such bonds drops below xoo\%, the bondholders, voting as a class, shall be entitled to elect at least a majority of the members of the board of directors; and $\S$ i 8 (a) (2) (c) requires that each issue of preferred stock entitle the holders, voting as a class, to elect at least two directors at all times, and, subject to the rights of bondholders, to elect a majority of directors if dividends are unpaid on the preferred stock for two years. Section I8 (c) provides that investment companies may not issue more than three classes of securities-one class of bonds, one class of preferred stock, and one class of common stock. And, finally, $\S 18$ (i) provides that every share of stock issued by a registered management company shall be a voting stock and shall have equal voting rights with every other outstanding voting stock. In addition, $\S 20(\mathfrak{a})$ subjects proxy solicitations by investment companies to the regulation to which solicitations relating to listed securities are already subject by reason of SEC regulations under $\S_{14}(a)$ of the Securities Exchange Act of 1934. 48 STAT. 895 (1934), as amended, 15 U.S.C. $\$ 78 n$ (1952). And, finally, $\S \times 6 \mathrm{a}$ is designed to prevent secret shifts in control by seriatim resignations of directors. See Tolins, supra note 6 , at 93-94; Notes, 4 r Colum. L. REv. 269, $281-82$ (1941), 88 U. PA. L. REv. 584, 607-10 (1940).

${ }^{\text {aq }}$ See especially, Barnard, Jackson, \& Motley, supra note 6. 
management, ${ }^{\phi 8}$ investment companies accumulate unusually large pools of liquid assets, ${ }^{69}$ which are naturally susceptible of a variety of uses by the management or the controlling stockholders. ${ }^{70}$ In connection with the Alleghany controversy, it is perhaps significant to note that the SEC Report disclosed several instances in which an investment company was used as a device to acquire control of a company or group of companies. ${ }^{71}$ Such an undertaking, of course, is not improper so long as it does not disappoint the reasonable investment expectations of the company's security holders. It does seem, however, that this latter contingency could be avoided only by the prophylactic measures of the Investment Company Act. For example, if the acquisition of control will constitute a fundamental shift in the company's investment policies, as stated in its registration statement, then section I3(a) of the act will require the approval of a majority of the company's outstanding voting securities. ${ }^{22}$ Moreover, the acquisition of control by the Alleghany Corporation was accompanied by certain "upstream loans"73 and

os "The underlying principles of investment trusts were the combination of funds by many small investors to lessen investment risks by diversification of investment, and the maintenance of specialized management at a moderate cost." Senate Committee on Banking and Currency, Stock Exchange Practicers, S. REP. No. 1455, 73d Cong., $2 \mathrm{~d}$ Sess. 333 (1934). See also SEC RePort pt. 4, c. II, at 373-75.

${ }^{00}$ See Jaretzki, supra note 6 , at 304-05, where it is observed that the significance of an investment company attaches not to the "pooling of funds," which occurs in the case of any corporation, but rather to "the use to which these funds are put."

70 "The liquidity of their capital assets made more easy their embezzlement or theft or their use for improper purposes." Id. at 307. See also SEC REPORT pt. 3, c. II, at I-3I; Notes, 8S U. PA. L. Rev. 584, 606 (1940), 4I Colum. L. Rev. 269, 272 (194I).

71 "A strong incentive for the formation of investment companies existed in the case of sponsors who were desirous of acquiring or perpetuating influence or control over industrial or financial enterprises." SEC REPORT pt. r, c. III, at \$9. The CentralIllinois Securities Corporation, for one example, together with H. M. Byllesby \& Co., arranged to purchase control of a utility holding company. The venture resulted in a loss of $\$ 1,730,691$. SEC REPORT pt. 3, c. II, at $169-74$.

73 "No registered investment company shall, unless authorized by the vote of a majority of its outstanding voting securities ... (3) deviate from its policy in respect of concentration of investments in any particular industry or group of industries as recited in its registration statement, or deviate from any fundamental policy recited in its registration statement pursuant to section $S(b)(2)$; or $(4)$ change the nature of its business so as to cease to be an investment company." 54 STAT. 8 II (1940), I5 U.S.C. $\$ 80 a-13($ 1952).

${ }^{73}$ In connection with the New York Central proxy contest (see note 2 supra), Alleghany expended approximately $\$ 1,078,000$, which is stated to "have been made on behalf of others, and it is anticipated that the Corporation will be reimbursed for the same in 1954." To the extent that this expenditure represents an advance or loan to 
"transactions with affiliated persons;" and the act specifically regulates such dealings in order to assure that those in control do not take advantage of a conveniently available fund for their own personal aggrandizement. $^{75}$

The dangers of unregulated investment company activity, however, are much more extensive than those which might be illustrated by the Alleghany history. ${ }^{76}$ Affliations with securities brokers or investment

or on behalf of controlling persons of Alleghany, it was an "upstream loan." Memorandum of the SEC as Intervenor, pp. 8-9, Louisville \& Jeffersonville Bridge and Railroad Co. Merger, etc. 295 I.C.C. II (1955).

${ }^{76}$ In July 1954, Clint Murchison and Sid Richardson sold New York Central stock to Alleghany, and, in connection with this sale, entered into joint venture agreements with Alleghany under which they each borrowed from the company the sum of $\$ 3,750,000$. Both men are directors of the New York Central and, therefore, are "affiliated persons" of IDS by virtue of its ownership of approximately $20 \%$ of the voting securities of IDS; and IDS is, in turn, controlled by Alleghany. Id. at 8 . See also How Young Got the Votes, Fortune, Aug. 1954, p. 87.

"As for "upstream loans," $\S 21$ provides that: "It shall be unlawful for any registered management company to lend money or property to any person, directly or indirectly, if ... (b) such person controls or is under common control with such registered company. ..." 54 STAT. 822 (1940), 15 U.S.C. \$ 80a-2 I (1952). "Control" is defined by section 2(a) (9). 54 STAT. 790 (1940), 15 U.S.C. \& 8oa-2 (a) (9) (1950).

"Transactions with affliated persons" are covered by $\S \mathrm{I}_{7}(\mathrm{a})$, which makes it unlawful for persons who are officers, directors, promoters, or persons affiliated with such persons knowingly to sell to or purchase from their investment company any securities or property, or borrow from such investment company. But $\S_{17}(\mathrm{~b})$ provides that the SEC may grant exemptions from subsection (a) if the transaction is fair and is consistent with the investment policies of the act. 54 STAT. 815 (1940), 15 U.S.C. \$ 80a-17 (1952). See the Atlantic Coast Line Co., 13 S.E.C. 719 (1943). The selfdealing practices to which this section was directed were among the foremost abuses which the SEC Report uncovered: "While the losses in a number of investment companies were attributable principally to the security market decline and general business decline, in many cases the substantial losses sustained by investment companies were the result of the numerous transactions which the sponsors, managers, officers, directors, and other controlling interests effected for their own account with the investment companies which they dominated." SEC REPORT pt. 3, c. I, at 22. See Jaretzki, supra note 6, at 317-24; Note, 41 Colvm. L. REv. 269, 288-91 (1941).

"The SEC memorandum submitted to the ICC on Sept. 14, 1954, cited several other transactions which would have been subject to regulation under the Investment Company Act. The last of Alleghany's interest in the $\mathrm{C} \& \mathrm{O} \mathrm{Ry}$. Co. was sold to Cyrus L. Eaton on January 18, 1954. Since Mr. Eaton was affiliated with the Portsmouth Steel Corporation, $18 \%$ of whose voting securities were owned by Allcghany, this was a transaction with an "affliated person" of an "affiliated person" within the meaning of $\$ 17(\mathrm{a})$. Memorandum of the SEC as Intervenor, p. 7, Louisville \& Jeffersonville Bridge and Railroad Co. Merger, etc. 295 I.C.C. 11 (1955). On January 20, 1950, Robert R. Young and Allan P. Kirby, directors of Alleghany, exchanged with the company their shares of Alleghany's preferred stock, on which there 
bankers, ${ }^{77}$ for example, open unusual opportunities for market support operations $^{78}$ and for the dumping of "sticky" issues. ${ }^{79}$ It is quite apparent that these and other practices ${ }^{80}$ with which the Investment Company Act is concerned must be regulated for the protection of the public investor, regardless of any incidental relationship which an investment company may acquire with the transportation industry.

\section{Resolution of the Conflict}

In view, therefore, of their respective interests in the regulation of investment companies that control railroads, there would appear to be no doubt as to which commission's jurisdiction it is most essential to preserve. It would be at least improvident to sacrifice the intensive

were arrearages of $\$ 103$ per share, for common stock in IDS. Section I7 (a) (2) would have applied to this exchauge. Id. at 13 . In 1949, Alleghany purchased over 9r\% of the outstanding voting stock of IDS, in violation of $\S 1_{2}(d)$, which provides that "it shall be unlawful for any registered investment company . . to purchase or otherwise acquire ... any security issued by ... (I) any other investment company...." Id. at 14. The evils of pyramiding, to which this section is directed, were examined extensively in the SEC REPORT pt. 3, c. VII, at 2721-95. See also Jaretzki, sicpra note 6 , at 325-26.

${ }^{77}$ In order to insure an independent board of directors, $\$$ ro(a) of the act provides that no more than $60 \%$ thereof may consist of investment advisers to the company; and $\S_{1} \mathrm{o}(\mathrm{b})$ provides that a majority of the board must be composed of persons who are not regular brokers for the company or principal underwriters of its securities, or investment bankers. 54 STAT. 806 (1940), I5 U.S.C. \$80a-ro (1952). Also, $\S 10(f)$ prohibits investment companies from purchasing securities underwritten by persons affliated with the investment company, unless the investment company itself is a principal underwriter of such securities, until after the termination of the underwriting syndicate. 54 STAT. 806 (1940), I5 U.S.C. \$80a-ro(f) (1952).

${ }^{78}$ The SEC REPORT disclosed, for example, that, following the market crash of October, 1929, the funds of the Chatham Phenix Allied Corporation were utilized to support the market price of the stock of Cbatham Phenix National Bank \& Trust Company. Froin these operations the company sustained a net loss of $\$ 88,073.93$. SEC REPORT pt. 3, c. II, at $13 x$.

${ }^{70}$ See 88 U. PA. L. REv. 584, 593 (1940); SEC RePort pt. 3, c. II, at 527-66.

${ }^{80}$ For example, $\S_{12}(a)$ of the act makes it unlawful for investment companies, in contravention of SEC rules, to trade on margin, participate in joint trading accounts, or sell short. 54 STAT. 808 (1940), 15 U.S.C. \$ 80a-12(a). But see Jaretzki, supra note 6 , at 324 . Also, $\S \mathrm{I2}_{2}(\mathrm{f})$ provides that an investment company may not purchase securities issued by another investment company if, as a result of such purchase, the company will have more than $3 \%$ of the outstanding voting securities of the other investment company. See note 76 supra. Finally, $\$$ I $5_{5}$ of the act prescribes certain requirements for the investment advisory and underwriting contracts of investment companies, 54 STat. 812 (1940), 15 U.S.C. $\$ 80 a-15$ (1952); and $\$ \$ 22$ and 23 deal with the distribution and repurchase or redemption of securities of investment companies. 54 Stat. 823,825 (1940), I 5 U.S.C. $\$ \$ 80 a-22,80 a-23$ (1952). See, generally, Jaretzki, supra note 6 , at 327-32. 
supervision of investment companies afforded by the Investment Company Act for whatever minor advantages are to be anticipated from the ICC's special competence in railroad matters. But because of the section 3(c) (9) exclusion, SEC regulation of Alleghany is possible only when the ICC does not assert its own jurisdiction.

\section{Cession of Jurisdiction by the ICC:}

In this connection, it is relevant to consider the SEC's contention that the ICC, in its discretion, has the authority not to subject a railroad holding company to its jurisdiction. ${ }^{81}$ In rejecting this contention, the ICC took the position that it could not avoid asserting general jurisdiction over Alleghany without ignoring the mandate of section $5(3) .^{82}$ The language of that section, however, would certainly indicate that the ICC has discretion in the matter; ${ }^{83}$ and, in addition, the ICC made no attempt to reconcile its position with several of its past decisions under section 5(3), in which it declined to assert jurisdiction over a noncarrier whose control of a carrier was only incidental to its principal business activity. ${ }^{84}$ Against this background of decisions, the ICC's

${ }^{81}$ Memorandum of the SEC as Intervenor, p. 18; second supplemental memorandum of the SEC as Intervenor, pp. 1-5, Louisville \& Jeffersonville Bridge and Railroad Co. Merger, etc., 295 I.C.C. I I (1955).

82 "Except that we have the power to impose just and reasonable conditions, we are bound to apply the provisions of the Interstate Commerce Act in the manner we consider best protects the interests of the public in the field of transportation in interstate commerce. We have no discretionary power to yield our jurisdiction to any statutory agency." Louisville \& Jeffersonville Bridge and Railroad Co. Merger, etc., I.C.C. Finance Docket No. 18656, Report of Division 4, Sheet 16 (1955). The full Commission was in accord with the view of Division 4. "As the division stated, we believe that unless Congress amends either or both of the statutes involved herein, the results which S.E.C. desires to achieve are not within our powers under the Interstate Commerce Act." 295 I.C.C. II, 14 (1955).

${ }^{83} 48$ STAT. 217 (1933), as amended, 49 U.S.C. $\$_{5}(3)$ (1952). The section provides that whenever a noncarrier, as authorized under $\S_{5}(2)$, acquires control of two or more carriers, it "shall, to the extent provided by the Commission in such order, be considered as a carrier subject to such of the following provisions as are applicable. ..." [Emphasis added.]

St See, for example, Valdosta So. R.R. Purchase, etc., 282 I.C.C. 705 (1952); Rockdale, Sandow \& Southern R.R. Co. Operation and Control, 282 I.C.C. 297 (1952); Arkansas \& L.M. Ry. Co., 282 I.C.C. 254 (1952); Cambria \& I.R. Co. Control, 275 I.C.C. 254 (1950); Saginaw Dock \& Terminal Co. Contract Carricr Application, 260 I.C.C. 657 (r945); Cuyahoga Valley Ry. Co. Control, 252 I.C.C. 683 (r 942); Warrier \& Gulf Nav. Co. Control, 250 I.C.C. 26 (1941). In fact, the Commission summarized its position with respect to the administration of $\$ 5(3)$ in the case of Shaver Forwarding Co. Purchase, etc., 260 I.C.C. 479, 495 (r945): "In the administration of the provisions of $\S 5(3)$ of the act, we have given consideration in 
position appears insupportable. ${ }^{85}$

\section{Conclusion:}

Assuming, then, that the ICC has the power to decline jurisdiction over Alleghany, a fairly satisfactory resolution of the conflict between the two commissions is possible. As has been demonstrated, SEC regulation of Alleghany under the Investment Company Act can be expected substantially to accommodate the regulatory interests of the ICC. It is a more open question, however, whether the ICC's regulatory interests would be as well represented in the case of an investment company whose portfolio, unlike Alleghany's, consisted predominantly of railroad securities. In such a situation, it is more than likely that the ICC's special competence in railroad financing would be, in some respects, quite useful, if not essential. Even so, since dual regulation is impossible, a choice between the commissions would still be necessary. In such a case, though, either choice would obviously be a compromise; and the optimum regulation could only be achieved through the combined efforts of the two commissions, each deferring to the other according to its respective competence.

If this is so, then perhaps congressional re-examination of section 3 (c) (9) of the Investment Company Act, as it affects railroad holding companies, is timely. There is already some evidence that its application to such companies was not intended by its sponsors; ${ }^{86}$ and a stat-

appropriate cases to the primary business or interests of the non-carrier person therein authorized to acquire control of a carrier, or of two or more carriers. Thus, we have exercised our plenary jurisdiction in the premises where the primary interest of the non-carrier is transportation [citing cases], but where such primary interest is not transportation, but the production of steel [citing cases], or the production of lumber [citing cases], we concluded that it was unnecessary to include in our orders any provisions subjecting the non-carriers to regulation under the Interstate Commerce Act in respect of reports, accounts, and so forth, or carriers, or of the issue of securities. ..." Admittedly, these cases are not authority for the wisdom of the ICC's cession of jurisdiction in the Alleghany matter; but they would appear to be persuasive of the proposition that the Commission does have the power not to assert its jurisdiction.

${ }_{85}$ This was also the conclusion reached by the district court. I34 F. Supp. I32, I 45 (S.D.N.Y. 1955).

${ }^{80}$ The legislative history of $\S_{3}(c)(g)$ strongly suggests that it was included in the Investment Company Act without any thought of avoiding dual regulation of railroad holding companies, but rather to preclude dual regulation of railroad subsidiaries. When originally introduced into the Senate as S. 3580 , the Investment Company Act contained no counterpart to the present $\S_{3}(\mathrm{c}) 9$. At the hearings on the bill, R. V. Fletcher, General Counsel of the Association of American Railroads, pointed out that passage of the Transportation Act of 1940, then pending, would have the effect of subjecting railroad subsidiaries and affliates to ICC jurisdiction with respect to the 
utory scheme which would allow dual regulation in appropriate situations seems quite desirable. However, the dual regulation permitted by such an amendment would necessarily require a large measure of cooperation between the two commissions-more, perhaps, than realistically can be expected in the light of the controversy precipitated by the Alleghany controversy.

issuance and sale of securities and the filing of reports. Mr. Fletcher feared that certain of these subsidiaries, however, might also be held to come within the definition of an investment company; and he urged the committee to pass an exemption which would avoid dual regulation. His closing remarks were as follows: "A careful examination of S. 3580 rather indicates that perhaps the bill was not intended to cover railroads and their subsidiaries. Certainly these subsidiaries are not investment companies in the ordinary sense of the word. However, there is langunge in section 3 of S. 3580 , as well as in section 6, dealing with exemptions, which leaves the matter in doubt. In order that all doubt may be removed, the Association of American Railroads is suggesting that S. 3580 be amended. ..." [Emphasis added.] Significantly, Mr. Fletcher made no reference to companies controlling carriers, but was concerned only with subsidiaries. Hearings before the Subcommittee of the Senate Committec ont Banking and Currency, 76th Cong. 3 d Sess. pt. 2, at 777-78 (1939). A subsequent exchange between Representative Cole and David Schenker at the hearings on H.R. roo65, an amended version of $S .3580$, indicate that $\S_{3}(c)(9)$ was actually drafted in the light of the effect on railroad subsidiaries of the Transportation Act of 1940. Hearings before a Subcommittee of the House Committee on Interstate and Foreign

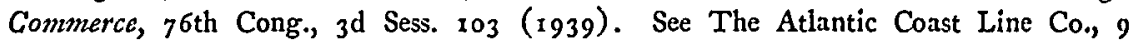
S.E.C. 680 (1941). 